\title{
Effect of Organ Site on Nuclear Matrix Protein Composition
}

\author{
Tracy S. Replogle-Schwab, Robert H. Getzenberg, Terry L. Donat, and Kenneth J. Pienta \\ The University of Michigan Comprehensive Cancer Center and Division of Hematology/Oncology, \\ Department of Internal Medicine, Ann Arbor, Michigan, 48109-0680 (T.S.R.-S., K.J.P.); University of \\ Pittsburgh Cancer Institute, Pittsburgh, Pennsylvania 15213-2582 (R.H.G.); Wayne State University \\ School of Medicine, Department of Otolaryngology/HNS, Detroit, Michigan 48201 (T.L.D.)
}

\begin{abstract}
The nuclear matrix has been linked to several important cellular functions within cells, such as DNA organization and replication, as well as regulation of gene expression. It has been reported that the nuclear matrix protein composition is altered in cells grown on different extracellular matrices in vitro. This study examined the nuclear matrix protein composition of tumors produced by MAT-LyLu (MLL) rat prostate tumor cells implanted at different organ sites within the rat. When high resolution two-dimensional gels were utilized to compare nuclear matrix protein composition to the prostate orthotopic tumor, it was found that there were distinct protein differences depending upon where the tumor grew. In particular, there were 14 proteins found in the lung, six proteins found in intramuscular, 17 proteins is the heart, and five proteins in the tail vein tumor tissue that were not present in the prostate orthotopic tumor tissue. Therefore, this study adds evidence to support that the nuclear matrix composition of a cell is dependent, at least in part, by the extracellular matrix and/or different cellular environments and may have a role in site-specific differences in tumor properties. 1996 Wiley-Liss, Inc.
\end{abstract}

Key words: MAT-LyLu (MLL), gene expression, two-dimensional electrophoresis, orthotopic, cancer, extracellular matrix

The structures and functions of a cell are dependent on a cell matrix system which extends from the cell periphery to the DNA [Getzenberg et al., 1990]. Experimental evidence of a cellular matrix system came when electron micrographs clearly demonstrated the linkages of the cellular periphery, cytoskeleton, and the nuclear matrix [Fey et al., 1984]. The physical connections between the nucleus and cytoskeleton have been reported to be functionally altered in transformed cells [Pienta and Coffey, 1992]. The tissue matrix system includes the linkages of the cell matrix to the extracellular matrix (ECM) [Getzenberg et al., 1990]. Extracellular signals within the ECM, when exposed to the appropriate receptor(s) on a cell membrane, can transverse into the cytoplasm and/or nucleus by utilizing these matrix networks.

Received December 18, 1995; accepted February 2, 1996.

Address reprint requests to Kenneth J. Pienta, The University of Michigan Comprehensive Cancer Center and Division of Hematology/Oncology, Department of Internal Medicine, 5510 MSRB I, 1150 West Medical Center Drive, Ann Arbor, MI 48109-0680.
Therefore, what a cell touches (i.e., ECM) helps determine what the cell will do. The ECM appears to control nuclear shape in rat hepatocytes and multiple studies have demonstrated that alterations in cell shape, determined at least in part by the matrix networks, can also induce DNA, RNA, and protein synthesis [Mooney et al., 1995]. DNA synthesis is regulated by cell shape and DNA metabolism appears to be linked with physical expansion of the cell and nucleus [Ingber et al., 1987; Folkman and Moscona, 1978]. Primary rat hepatocytes, when grown on different extracellular matrices, have been demonstrated to exhibit altered gene expression [Hansen et al., 1994]. mRNA expression has also been reported to be altered when cells were grown on different extracellular matrices. In particular, the amount of insulin mRNA present in cultured hepatocytes has been shown to be dependent upon the ECM used [Muschel et al., 1986].

The nuclear matrix is an important part of the cell's networking system. The nuclear matrix is the RNA-protein skeleton of the nucleus which contributes to the structural and functional or- 
ganization of DNA. The nuclear matrix consists of peripheral lamins, pore complexes, residual nucleoli, and a RNA-protein network [Berezney and Coffey, 1974; Berezney and Buchholtz, 1981; Barrack and Coffey, 1982; Nelson et al., 1986; Berezney, 1991; Pienta et al., 1991a]. The nuclear matrix has been demonstrated to play roles in several functions, including DNA organization and replication, RNA synthesis and transport, and the regulation of gene expression. The nuclear matrix provides the framework on which loop domains of DNA are organized. The sites at which DNA is attached to the matrix are called matrix associated regions or scaffold attachment regions and these attachment sites have been identified as the location of actively transcribed genes and viruses [Robinson et al., 1983; Ciejek et al., 1983], including chicken lysozyme locus [McKnight et al., 1992], SV40 [Abulafia et al., 1984], and vitellogenine II [Jost and Seldran, 1984]. A number of components important in gene regulation including steroid receptors and transcription factors have been demonstrated to be associated with the nuclear matrix [Barrack and Coffey, 1980; Merriman et al., 1995; Nardozza et al., in press]. The nuclear matrix proteins have been shown to vary in a cell type-specific manner indicating that the nuclear matrix may play an important role in the tissue-specific three-dimensional organization of DNA [Getzenberg and Coffey, 1990; Fey et al., 1984; Getzenberg et al., 1991a]. Since the nuclear matrix appears to play major roles in the normal functions of a cell, it has been proposed that the alterations of these nuclear matrix proteins may play a role in altered gene function. Evidence of this is found in cancer cells, where altered cell function is paralleled by changes in nuclear matrix composition [Berezney et al., 1979; Getzenberg et al., 1991; Khanuja et al., 1993; Partin et al., 1993; Keesee et al., 1994; Donat et al., 1996; Getzenberg et al., in press].

Cells grown on different extracellular matrices have been reported to have altered morphologic and phenotypic characteristics. Normal rat kidney (NRK) cells plated onto matrigel (a tumor secreted basement membrane) exhibited changes in cell area, morphology, nuclear/ cytoplasmic ratios, cell motility, as well as a loss of contact inhibition [Pienta et al., 1991b]. The nuclear matrix composition of these cells were found to be altered as well [Getzenberg et al., 1991b]. Comparisons of fetal rat calvaria osteoblast cells grown on either collagen type I or plastic matrices were also found to exhibit alterations in gene expression, mRNA levels, and matrix mineralization [Lynch et al., 1995]. The purpose of this study, therefore, was to examine the differences of nuclear matrix protein composition in vivo by comparing nuclear matrix protein compositions of tumors grown at different organ sites in the rat by injections of the MLL prostate cancer cell line.

\section{METHODS \\ Cell Lines}

MAT-LyLu (MLL, Metastatic, Anaplastic, Tumor to Lymph nodes and Lungs) cell line was maintained in RPMI $1640^{-}$supplemented with $10 \%$ fetal bovine serum and $1 \%$ penicillin/ streptomycin solution. Cell culture reagents were obtained from Sigma (St. Louis, MO).

\section{Tumor Samples}

Cells growing in culture were detached using trypsin followed by neutralization with media. Cells were pelleted and resuspended in Hanks Buffered Salt Solution (HBSS). One million cells $(100 \mu \mathrm{l})$ were injected intramuscularly, directly into the tail vein, heart, lung, or prostate of male Copenhagen rats (200-250 g) (Harlan, Indianapolis, IN). One injection was given per rat. Two to four rats were injected per organ site. Tumors were allowed to grow from 2-4 weeks to ensure ample tumor size. The largest tumor produced at each site was used for nuclear matrix isolation (i.e., tumors were not mixed). Tumors were removed and placed into $1 \times$ phosphate buffered saline containing $1 \mathrm{mM}$ phenylmethlsulfonyl fluoride (PMSF) on ice to inhibit protease activity. Tissue was dounced on ice for $15 \mathrm{~min}$ followed by centrifugation at 780 rpm for $10 \mathrm{~min}$. Supernatant was removed and the cells underwent nuclear matrix isolation.

\section{Analysis of Nuclear Matrix Proteins}

Nuclear matrix preparation. Nuclear matrices were prepared using the methodologies described elsewhere [Fey and Penman, 1988; Getzenberg et al., 1990]. Pellets were suspended in $0.5 \%$ Triton X-100 and $2 \mathrm{mM}$ vanadyl ribonucleoside and placed on ice for $20 \mathrm{~min}$ to release the lipids and soluble protein. Soluble cytoskeletal elements were released following a 0.25 $\mathrm{M}$ ammonium salt extraction with vanadyl ribonucleoside for $10 \mathrm{~min}$ on ice. The pellet was resuspended in chromatin buffer $(50 \mathrm{mM} \mathrm{NaCl}$, 


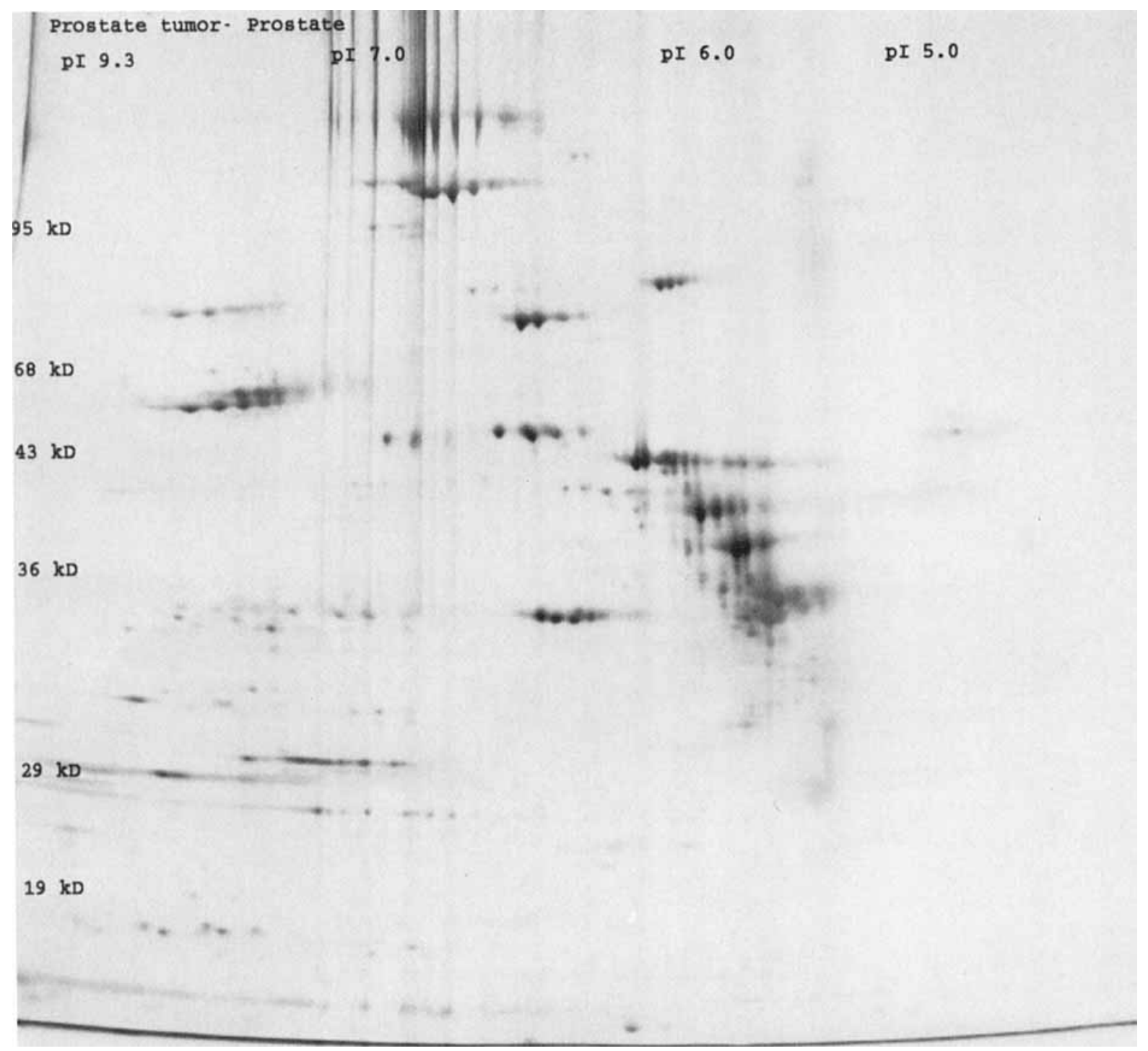

Fig. 1. High-resolution two-dimensional gel electrophoresis of a prostate tumor derived from an injection of MLL cells. This gel was used to compare the remaining nuclear matrix tumor protein compositions.

$300 \mathrm{mM}$ sucrose, $10 \mathrm{mM}$ Pipes (pH 6.8), $5 \mathrm{mM}$ $\mathrm{MgCl}_{2}, 0.5 \%$ Triton X-100, $1.2 \mathrm{mM}$ phenylmethylsulfonyl fluoride (PMSF), and $100 \mu \mathrm{g} / \mathrm{ml}$ DNase 1) and incubated for $20 \mathrm{~min}$ at $20^{\circ} \mathrm{C}$. Samples were centrifuged and resuspended in cytoskeleton buffer $(100 \mathrm{mM} \mathrm{NaCl}, 300 \mathrm{mM}$ sucrose, $10 \mathrm{mM}$ Pipes ( $\mathrm{pH} 6.8$ ), $5 \mathrm{mM} \mathrm{MgCl}_{2}$, $0.5 \%$ Triton X-100, $1.2 \mathrm{mM}$ PMSF, and $25 \mu \mathrm{g} / \mathrm{ml}$ RNase A) for $10 \mathrm{~min}$ at $20^{\circ} \mathrm{C}$. The remaining fraction was disassembled by overnight dialysis with a buffer containing $8 \mathrm{M}$ urea, $20 \mathrm{mM}$ 2-(N-morpholino)ethanesulfonic acid $(\mathrm{pH} 6.6)$, $1 \mathrm{mM}$ ethyleneglycol bis( $\beta$-aminoethyl ether)$\mathrm{N}, \mathrm{N}, \mathrm{N}^{\prime}, \mathrm{N}^{\prime}$-tetraacetic acid, $1 \mathrm{mM}$ PMSF, 0.1 $\mathrm{mM} \mathrm{MgCl} 2$, and 1\% 2-mercaptoethanol. The re- maining intermediate filaments were reassembled using a buffer containing $0.15 \mathrm{M} \mathrm{KCl}$, $25 \mathrm{mM}$ imidazole hydrochloride, $5 \mathrm{mM} \mathrm{MgCl}{ }_{2}$, $2 \mathrm{mM}$ dithiothreitol, $0.125 \mathrm{mM}$ ethyleneglycol bis ( $\beta$-aminoethyl ether)-N,N, $N^{\prime}, N^{\prime}$-tetraacetic acid, and $0.2 \mathrm{mM}$ PMSF and separated out by centrifugation. The soluble nuclear matrix proteins were ethanol precipitated at $-20^{\circ} \mathrm{C}$. All solutions contained freshly made $1 \mathrm{mM}$ PMSF to inhibit serine proteases. The protein was resuspended in $20 \mu \mathrm{l}$ of sample buffer ( $9 \mathrm{M}$ urea, $65 \mathrm{mM}$ CHAPS, $140 \mathrm{mM}$ dithiothreitol, and $2.2 \%$ ampholytes). Coomassie Plus assay (Pierce, Rockford, IL) was used for protein determination using bovine serum albumin as a standard. 


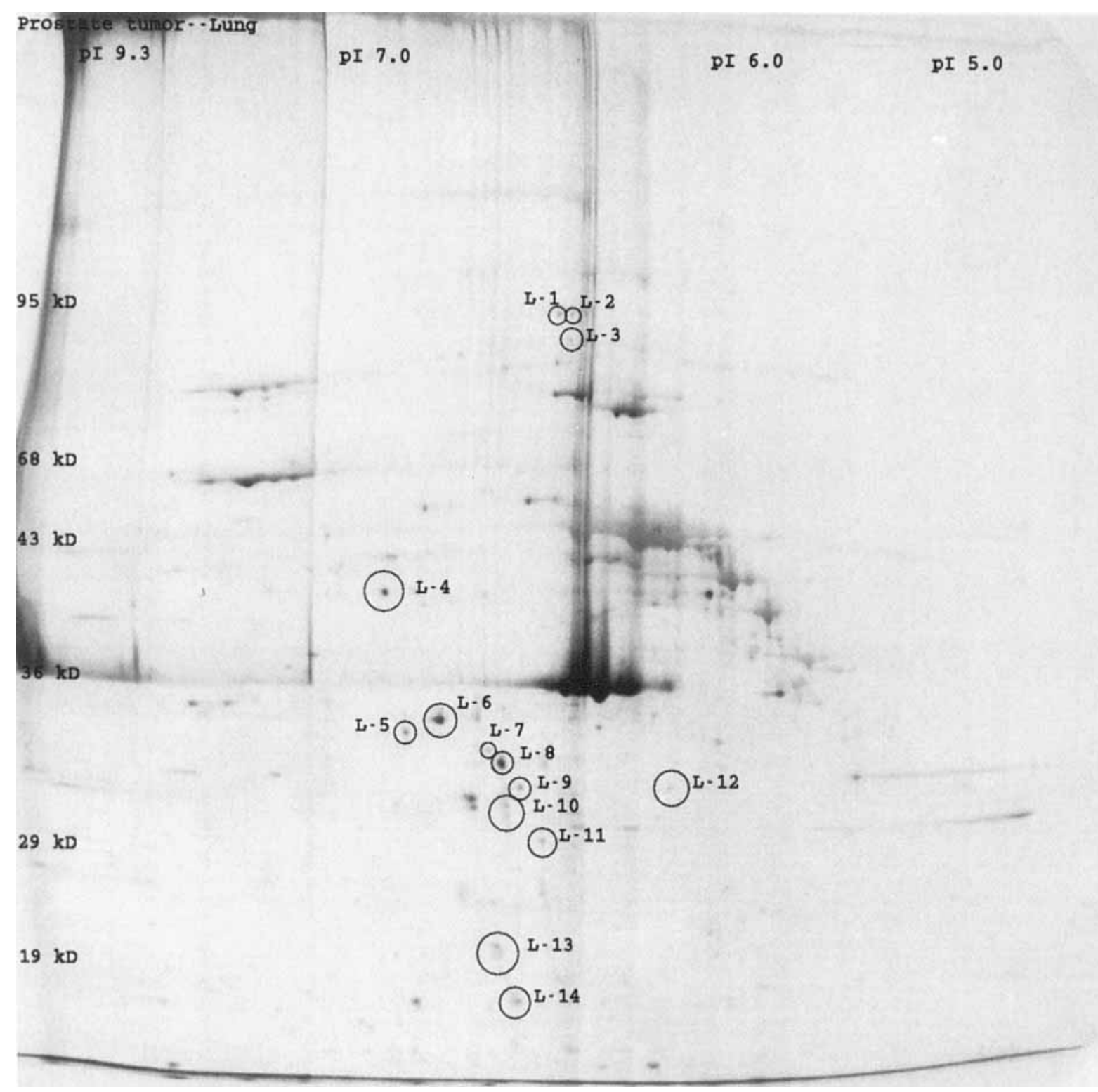

Fig. 2. High-resolution two-dimensional gel electrophoresis of a lung tumor derived from an injection of MLL cells. L-1 through L-14 represent nuclear matrix proteins that were not found in the prostate tumor nuclear matrix composition.

\section{Two-Dimensional Electrophoresis}

High resolution two-dimensional electrophoresis was carried out using the Investigator 2-D Electrophoresis System from Oxford Glycosystems (Bedford, MA). Tube gels were cast followed by prefocusing until the maximum voltage reached 1500 volts. $40 \mu \mathrm{g}$ of sample was loaded onto glass tubes with a $1 \mathrm{~mm}$ inner diameter and isoelectric focusing was carried out using $\mathrm{pH}$ 3-10 ampholytes optimized for separation of cellular proteins (Oxford Glycosystems) for 18,000 volt $h$. Tube gels were extruded and incubated in gel equilibration buffer $(0.3 \mathrm{M}$ Tris base, $0.075 \mathrm{M}$ Tris- $\mathrm{HCl}, 3.0 \%$ sodium dodecyl sulfate, $50 \mathrm{mM}$ dithiothreitol, and $0.01 \%$ bromophenol blue) for two min at room temperature. Each tube gel was placed on top of a $10 \%$ polyacrylamide gel and run for approximately $5 \mathrm{~h}$ at $20,000 \mathrm{~mW}$ per gel. Gels were fixed overnight in $50 \%$ methanol $/ 10 \%$ acetic acid, enhanced with $5 \%$ gluteraldeyde followed by silver staining using an Accurate Chemical silver staining kit (Accurate Chemical Co., Inc., Westbury, NY) as described elsewhere [Wray et al., 1981]. 


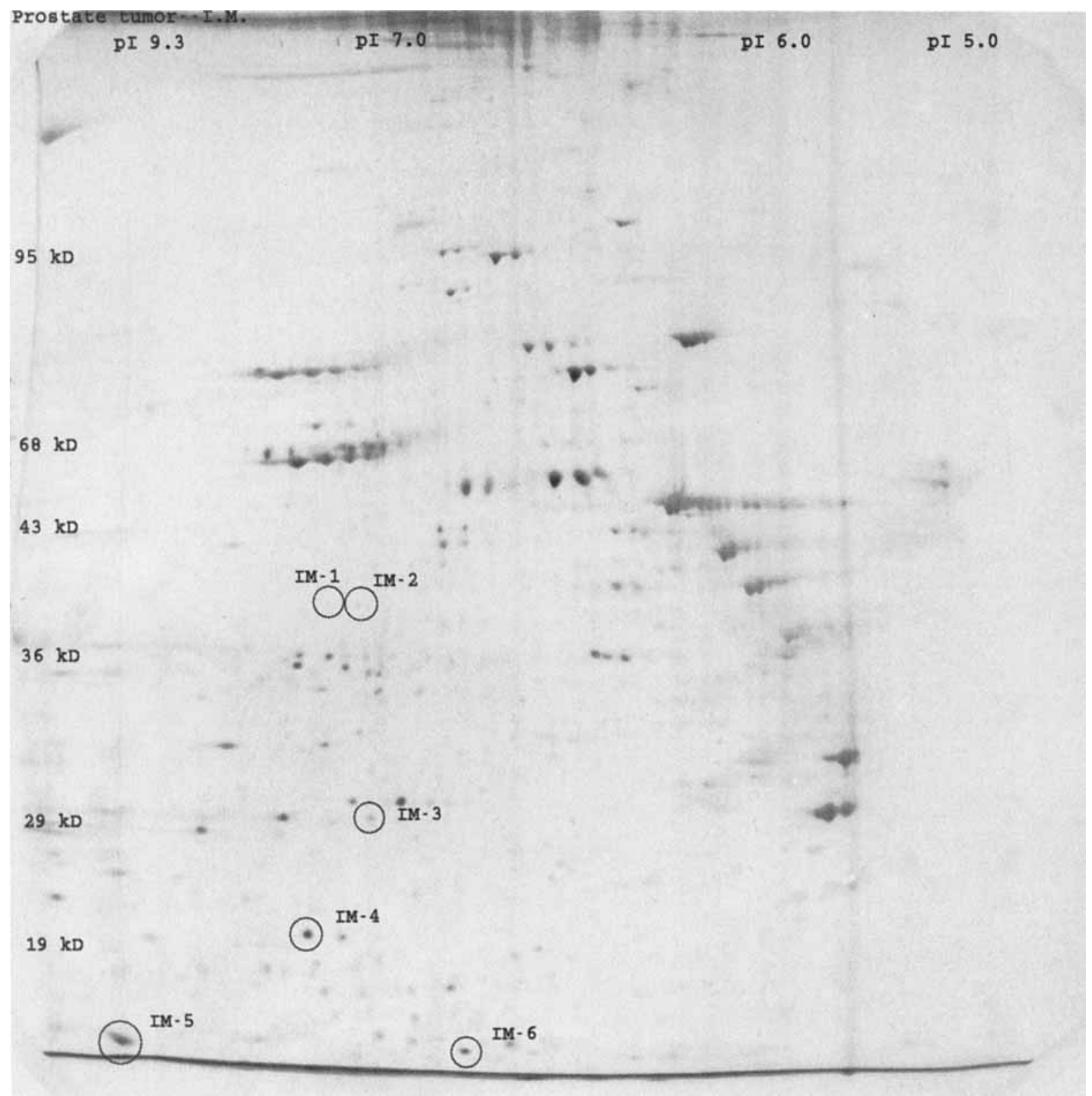

Fig. 3. High-resolution two-dimensional gel electrophoresis of an intramuscular tumor derived from an injection of MLL cells. IM-1 through IM-6 represent nuclear matrix proteins that were not found in the prostate tumor nuclear matrix composition.

Protein molecular weight standards were obtained from Diversified Biotechnology (Boston, MA). Isoelectric points were determined using BDH carbamylated standards (Gallard-Schlesinger, Carle Place, NY) and Sigma Chemical Co. (St. Louis, MO). When sufficient tumor material was available, multiple gels were run for each sample. Only protein spots clearly and reproducibly observed in all the gels of a sample type were counted as actually representing the nuclear matrix components. The gels were ana- lyzed using the BioImage 2D Electrophoresis Analysis System (BioImage, Ann Arbor, MI) which matches protein spots between gels and databases the gels and protein spots. Organ sites were compared to the gel produced by MLL cells injected into the orthotopic site of the prostate.

\section{RESULTS}

This study investigated the nuclear matrix protein composition from MLL prostate cancer cells growing at various organ sites in the rat. 


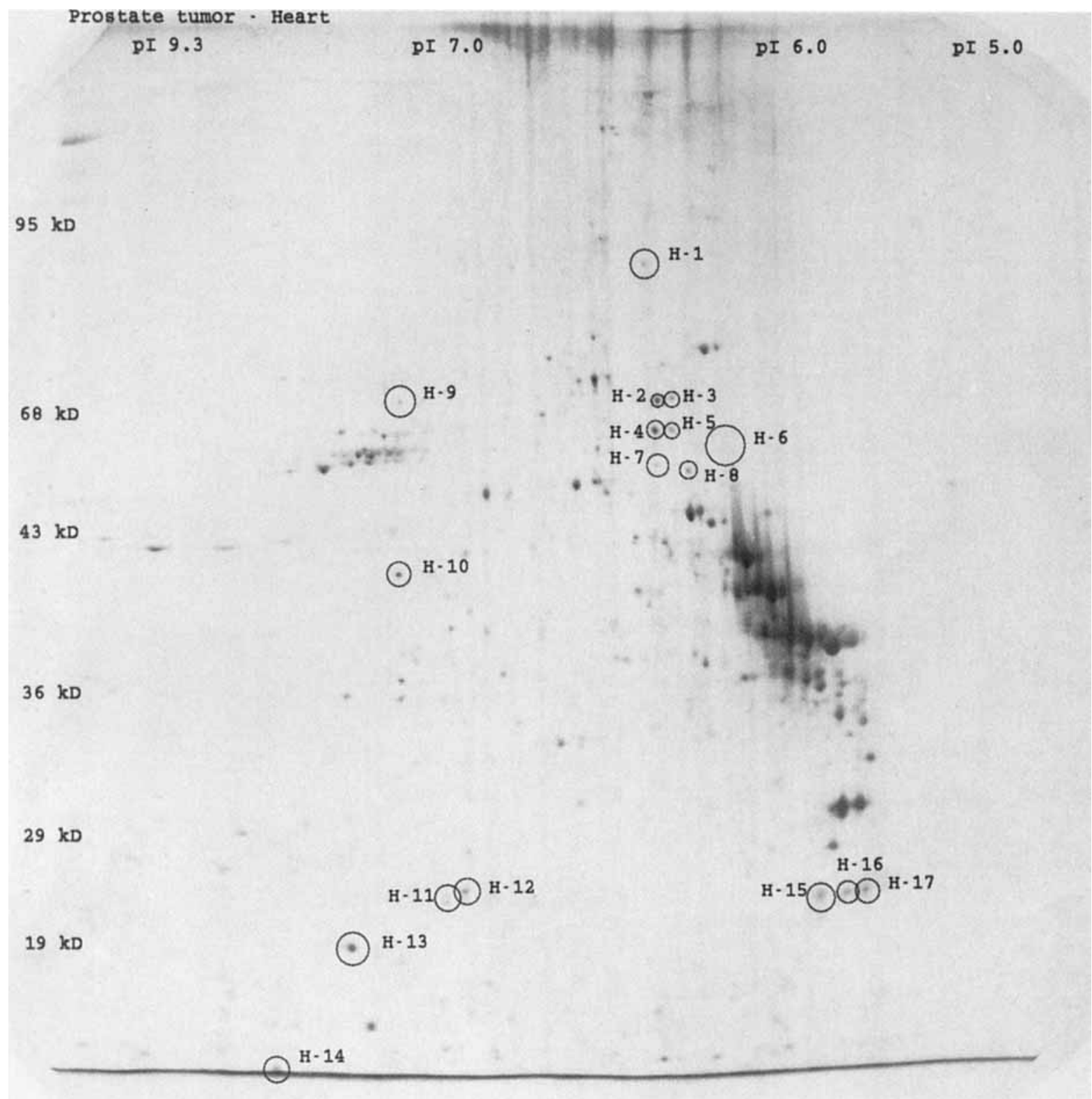

Fig. 4. High-resolution two-dimensional gel electrophoresis of a heart tumor derived from an injection of MLL cells. $\mathrm{H}-1$ through $\mathrm{H}-17$ represent nuclear matrix proteins that were not found in the prostate tumor nuclear matrix composition.

MLL prostate cancer cells were injected into the prostate, lung, heart, intramuscular, and tail vein producing tumors which were used for the isolation of nuclear matrix. Nuclear matrix samples were analyzed by their protein pattern revealed by two-dimensional electrophoresis. The heart, lung, intramuscular, and tail vein nuclear matrix protein compositions were compared only to the prostate tumor nuclear matrix pattern. This comparison was chosen since the MLL cell line was originally derived from a rat prostate tumor. Upon comparison, there were distinct protein differences, as well as common proteins, seen in all of the organ nuclear matrix protein compositions when compared to the prostate derived nuclear matrix. Figure 1 shows the twodimensional nuclear matrix pattern of the prostate derived tumor by which all other gels were compared. Approximately 150 proteins spots were identified ranging in size from $10-200 \mathrm{kD}$ 


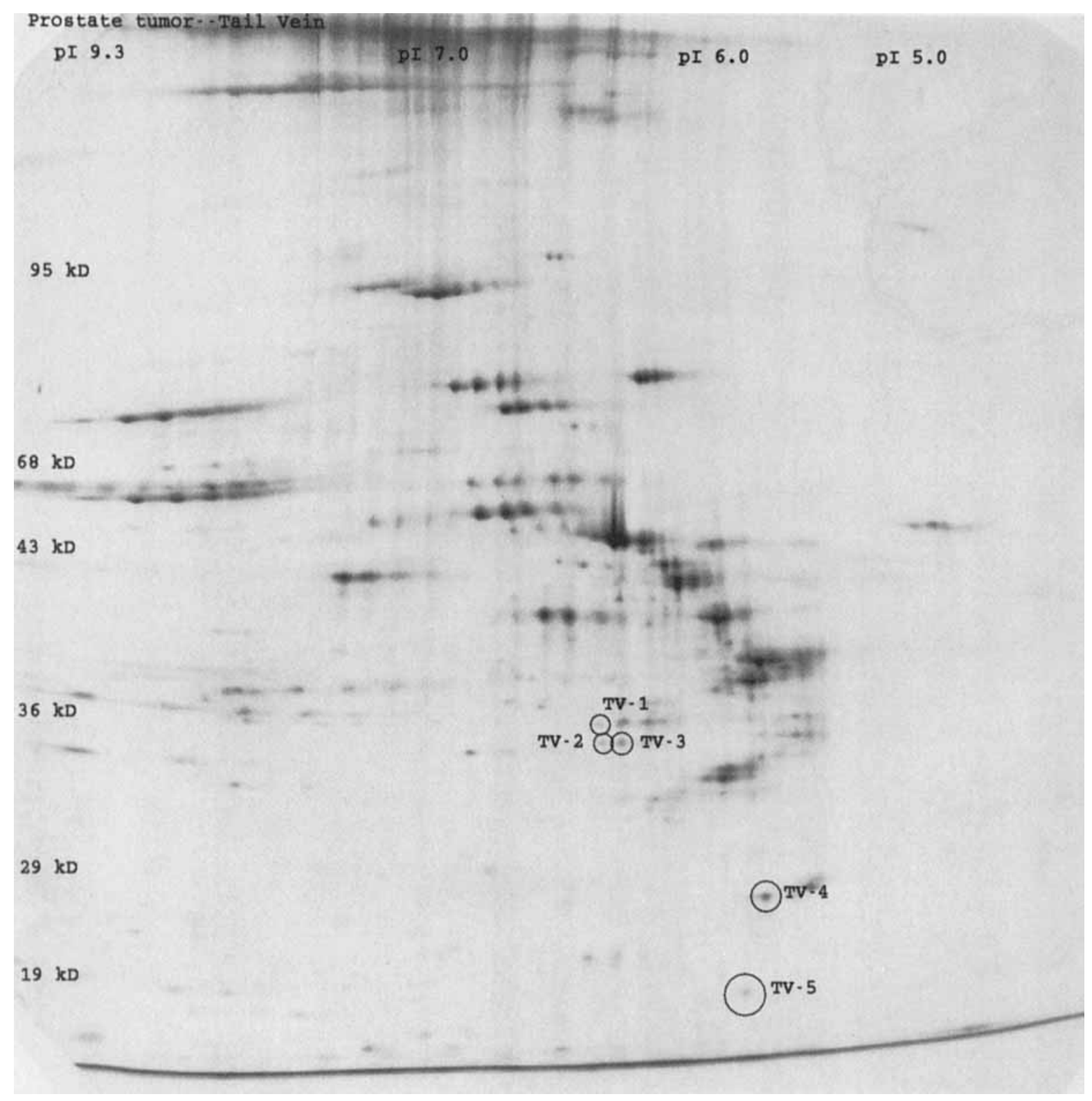

Fig. 5. High-resolution two-dimensional gel electrophoresis of a tail vein tumor derived from an injection of MLL cells. TV-1 through TV-5 represent nuclear matrix proteins that were not found in the prostate tumor nuclear matrix composition.

and pI from 5.0-9.3. When compared to the prostate protein pattern, fourteen proteins were identified as being present only in the lung (L-1 through L-14) (Fig. 2). The proteins ranged from approximately $18 \mathrm{kD}-95 \mathrm{kD}$ while the $\mathrm{pI}$ ranged from 6.2-7.0. Seven proteins (L5-L-11) were present in a cluster of $30-36 \mathrm{kD}$ and $\mathrm{pI}$ 6.6-6.9. Six proteins were found that were only present in the intramuscular tumor tissue (IM-1 through IM-6) (Fig. 3). These proteins ranged from approximately $14 \mathrm{kD}-40 \mathrm{kD}$ with pIs from 6.9-9.4. Seventeen proteins ( $\mathrm{H}-1$ through $\mathrm{H}-17$ ) were found only in the heart tumor tissue when compared to the prostate nuclear matrix pattern (Fig. 4) and ranged from $14-89 \mathrm{kD}$ and pIs from 6.0-8.8. H2-H8 were identified as a distinct group of proteins of $55-70 \mathrm{kD}$ and pI $6.1-6.3$. Five proteins (TV-1 through TV-5) were present in tail vein tumor tissue and not in the prostate tumor tissue (Fig. 5). These proteins ranged 


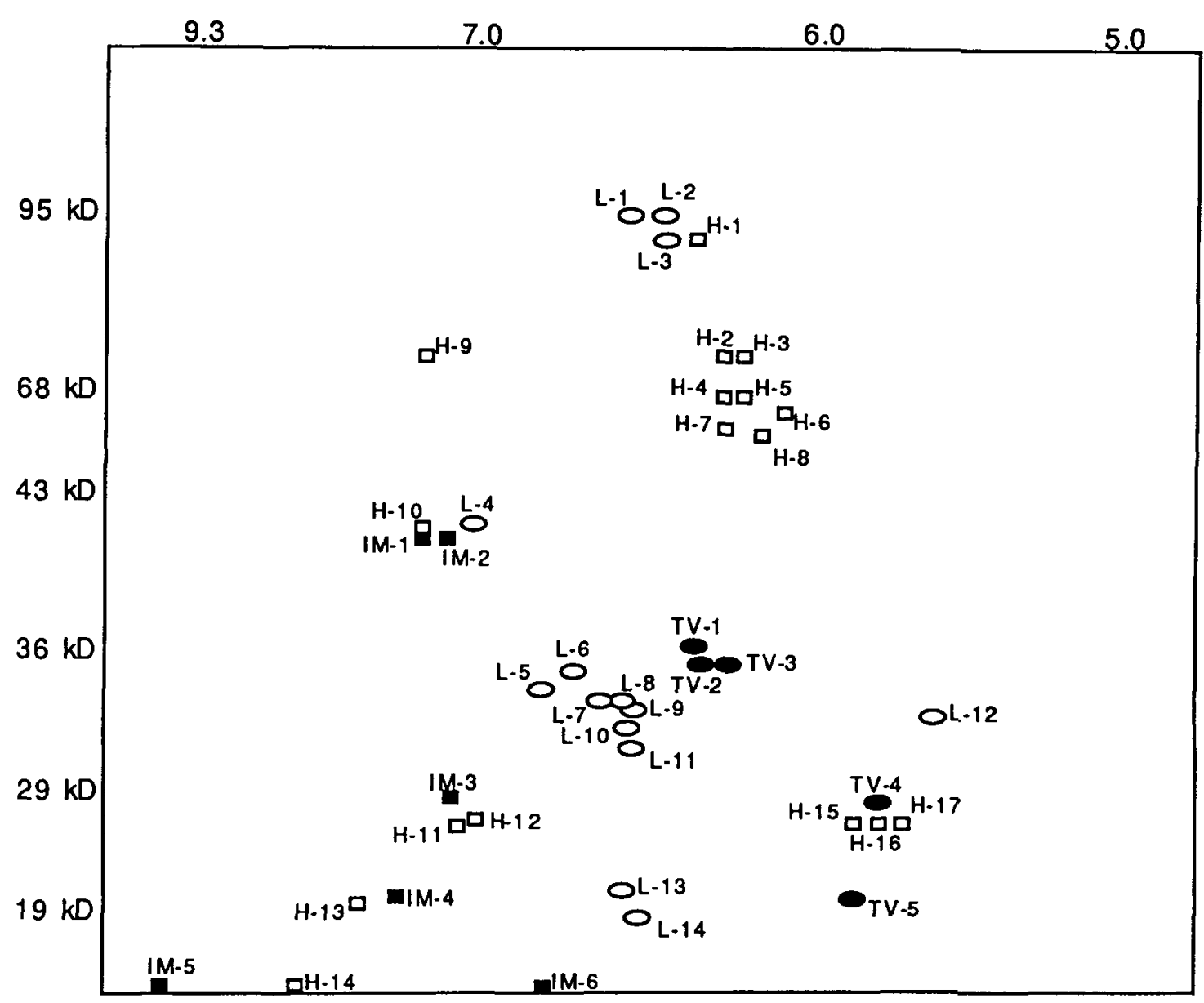

Fig. 6. A schematic representation of the high-resolution two-dimensional electrophoresis of the nuclear matrix proteins from MLL-producing tumors in the lung $\bigcirc$ (L-1 through L-14), intramuscular $\mathbf{\square}$ (IM-1 through IM-6), tail vein - (TV-1 through TV-5), and heart $\square(\mathrm{H}-1$ through $\mathrm{H}-17)$ when compared to the prostate tumor. Only protein differences are shown.

from approximately $19-36 \mathrm{kD}$ and $\mathrm{pIs}$ from 6.0-6.4. Figure 6 is a schematic representation of all of the different nuclear matrix proteins seen in all of the tumor tissues studied upon comparison to the prostate derived tumor.

\section{DISCUSSION}

The nuclear matrix has been implicated in critical functions of the cell, including replication, DNA organization, and transcription. Upon comparison of nuclear matrices from normal cells and their cancerous counterparts, it was found that distinct differences do exist [Berezney et al., 1979; Getzenberg et al., 1991; Khanuja et al., 1993; Partin et al., 1993; Keesee et al., 1994; Donat et al., 1996; Getzenberg et al., in press]. This study was undertaken to compare the nuclear matrix protein compositions in vivo of MLL prostate tumors growing at other organ sites in the rat. Upon comparison of the various organ sites to the nuclear matrix protein pattern produced by the prostate tumor, it was found that there were proteins present in the various tumor types that were not present in the tumor of the prostate. At least 17 proteins were present in the heart, six proteins in the muscle, 14 proteins in the lung, and five proteins in the tail vein that were not found in the prostate tumor. These proteins appeared to be organ specific and are listed in Table I.

Different expression of nuclear matrix proteins produced by the same cell line when grown at various organ sites may be due to the different environmental conditions at the various organs. Organs of the body are subjected to different macro- and microenvironments which may cause alterations in the transcriptional activity of genes as well as DNA replication resulting in different expression of nuclear matrix proteins. Different environments can be caused by the 
Table I. Proteins Present in Heart (H-1 Through H-17), Intramuscular (IM-1 Through IM-6), Lung (L-1 Through L-14), and Tail Vein (TV-1 Through TV-5) Not Found in the Prostate

\begin{tabular}{lcc}
\hline Designation & Molecular mass & Isoelectric point \\
\hline H-1 & $89 \mathrm{kD}$ & 6.4 \\
H-2 & $70 \mathrm{kD}$ & 6.3 \\
H-3 & $70 \mathrm{kD}$ & 6.2 \\
H-4 & $66 \mathrm{kD}$ & 6.3 \\
H-5 & $66 \mathrm{kD}$ & 6.2 \\
H-6 & $60 \mathrm{kD}$ & 6.1 \\
H-7 & $58 \mathrm{kD}$ & 6.3 \\
H-8 & $55 \mathrm{kD}$ & 6.2 \\
H-9 & $70 \mathrm{kD}$ & 7.6 \\
H-10 & $41 \mathrm{kD}$ & 7.6 \\
H-11 & $23 \mathrm{kD}$ & 7.1 \\
H-12 & $24 \mathrm{kD}$ & 7.0 \\
H-13 & $19 \mathrm{kD}$ & 8.1 \\
H-14 & $14 \mathrm{kD}$ & 8.8 \\
H-15 & $24 \mathrm{kD}$ & 6.0 \\
H-16 & $24 \mathrm{kD}$ & 6.1 \\
H-17 & $24 \mathrm{kD}$ & 6.1 \\
IM-1 & $40 \mathrm{kD}$ & 7.6 \\
IM-2 & $40 \mathrm{kD}$ & 7.3 \\
IM-3 & $29 \mathrm{kD}$ & 7.2 \\
IM-4 & $20 \mathrm{kD}$ & 7.9 \\
IM-5 & $14 \mathrm{kD}$ & 9.4 \\
IM-6 & $14 \mathrm{kD}$ & 6.9 \\
L-1 & $95 \mathrm{kD}$ & 6.6 \\
L-2 & $95 \mathrm{kD}$ & 6.5 \\
L-3 & $89 \mathrm{kD}$ & 6.5 \\
L-4 & $41 \mathrm{kD}$ & 7.0 \\
L-5 & $34 \mathrm{kD}$ & 6.9 \\
L-6 & $35 \mathrm{kD}$ & 6.8 \\
L-7 & $33 \mathrm{kD}$ & 6.7 \\
L-8 & $33 \mathrm{kD}$ & 6.7 \\
L-9 & $32 \mathrm{kD}$ & 6.6 \\
L-10 & $31 \mathrm{kD}$ & 6.6 \\
L-11 & $30 \mathrm{kD}$ & 6.6 \\
L-12 & $32 \mathrm{kD}$ & 6.2 \\
L-13 & $20 \mathrm{kD}$ & 6.7 \\
L-14 & $18 \mathrm{kD}$ & 6.6 \\
TV-1 & $36 \mathrm{kD}$ & 6.4 \\
TV-2 & $35 \mathrm{kD}$ & 6.4 \\
TV-3 & $35 \mathrm{kD}$ & 6.3 \\
TV-4 & $28 \mathrm{kD}$ & 6.1 \\
TV-5 & $19 \mathrm{kD}$ & 6.0 \\
\hline & & \\
& & \\
\hline
\end{tabular}

presence of different hormones and/or varying levels of hormones, variations in blood supply, or other chemical or electrical signals that are in direct contact with the cell.

A second possibility for the altered nuclear matrix protein compositions may be due to the differing extracellular matrices and normal or- gan cells that are in direct contact with the tumor cells. There is a great deal of evidence to suggest that what a cell touches (i.e., the extracellular matrix) plays a major role in determining how a cell functions. Investigations into the effects of differing extracellular matrices on various cells have been reported. In particular, normal rat kidney cells (NRK) and Kirsten-rats transformed normal rat kidney cells (KNRK), when plated onto matrigel (a basement membrane secreted by sarcoma cells) were found to adopt a morphologic and phenotypic characteristics that closely resemble KNRK cells [Pienta et al., 1991b]. This suggests that matrigel may cause morphologic transformations through unknown mechanisms. These observations were further studied by the same laboratory using high resolution two-dimensional electrophoresis analysis [Getzenberg et al., 1991]. It was found that there were distinct protein differences present in NRK and KNRK cells grown on different extracellular matrices. Such changes in the nuclear matrix protein composition have been suggested to be influenced by transcription factor binding to "extracellular matrix-response elements" present in promoters in some genes, such as $\beta$-casein [Boudreau et al., 1995]. Although there were differences in the nuclear matrix protein composition between the different organ sites within the rat, differences in the prostate-specific gene expression were not examined. Analysis of these nuclear matrix protein differences will begin to differentiate between these potential explanations.

The nuclear matrix patterns from each tumor type were produced within a single rat (i.e., multiple tumors at the same organ site produced in different rats were not individually analyzed). Although their may be differences if one were to examine the same tumor type produced by different rats, we feel that these differences would be minor due to the fact that the rats utilized in this study were from the same genetic background and exposed to the same conditions. In summary, nuclear matrix protein differences were seen in tumors produced by MLL prostate cancer cells in various organ sites when compared to the tumor produced by at the prostate. Such differences add evidence to the environmental influence on nuclear components in the cell which may in turn cause differential expression of genes. 


\section{REFERENCES}

Abulafia R, Ben-Zeev A, Hay N, and Aloni Y (1984): Control of late simian virus 40 transcription by the attenuation mechanism and transcriptionally active ternary complexes are associated with the nuclear matrix. J Mol Biol 172:467-487.

Barrack ER, Coffey DS (1980): The specific binding of estrogens and androgens to the nuclear matrix of sex hormone responsive tissues. J Biol Chem 255:7265-7275.

Barrack ER, Coffey DS (1982): Biological properties of the nuclear matrix: steroid hormone binding. Recent Prog Horm Res 38:133-195

Berezney R (1991): The nuclear matrix: a heuristic model for investigating genomic organization and function in the cell nucleus. J Cell Biochem 47:109-123.

Berezney R, Buchholtz LA (1981): Dynamic association of replicating DNA fragments with nuclear matrix of regenerating liver. Exp Cell Res 132:1-13.

Berezney R, Coffey DS (1974): Identification of a nuclear protein matrix. Biochem Biophys Res Comm 60:14101417.

Berezney R, Basler J, Hughes BB, Kaplan SC (1979): Isolation and characterization of the nuclear matrix from Zajdela ascites hepatoma cells. Cancer Res 39:3031-3039.

Boudreau N, Myers C, Bissell MJ (1995): From laminin to lamin: regulation of tissue-specific gene expression by the ECM. Trends Cell Biol 5:1-4.

Ciejek EM, Tsai MJ, O'Malley BW (1983): Actively transcribed genes are associated with the nuclear matrix. Nature 306:607-609.

Donat TL, Sakr W, Lehr JE, Pienta KJ (1996): Nuclear matrix protein alteration in intermediate biomarkers in squamous cell carcinoma of the head and neck. Otolaryngol Head Neck Surg, in press.

Fey EG, Penman S (1988): Nuclear matrix proteins reflect cell type of origin in cultured human cells. Proc Natl Acad Sci U S A 85:121-125.

Fey EG, Wan KM, Penman SP (1984): Epithelial cytoskeletal framework and nuclear matrix-intermediate scaffold: three-dimensional organization and protein composition. J Cell Biol 98:1973-1984.

Folkman J, Moscona A (1978): Role of cell shape in growth control. Nature 273:345-349.

Getzenberg RH, Pienta KJ, Coffey DS (1990): The tissue matrix: cell dynamics and hormone actin. Endocr Rev 11:399-417.

Getzenberg RH, Pienta KJ, Huang EY, Coffey DS (1991): Identification of nuclear matrix proteins in the cancer and normal rat prostate. Cancer Res 51:6514-6520.

Getzenberg RH, Pienta KJ, Huang EYW, Murphy BC, Coffey DS (1991): Modifications of the intermediate filament and nuclear matrix networks by the extracellular matrix. Biochem Biophys Res Comm 179:340-344.

Getzenberg RH, Konety BR, Oeler TA, Quigley MM, Hakam A, Becich MJ, Bahnson RR: Bladder cancer associated nuclear matrix proteins. Cancer Res, in press.

Hansen LK, Mooney DJ, Vacanti JP, Ingber DE (1994): Integrin binding and cell spreading on extracellular matrix act at different points in the cell cycle to promote hepatocyte growth. Mol Biol Cell 5:967-975.
Ingber DE, Madri JA, Folkman J (1987): Endothelial growth factors and extracellular matrix regulate DNA synthesis through modulation of cell and nuclear expansion. In vitro Cell Dev Biol 23:387-394.

Jost JP, Seldran M (1984): Association of transcriptionally active vitellogenin II gene with the nuclear matrix of chicken liver. EMBO J 3:2005-2008.

Keesee SK, Meneghini MD, Szaro RP, Wu YJ (1994): Nuclear matrix proteins in human colon cancer. Proc Natl Acad Sci U S A 91:1913-1916.

Khanuja PS, Lehr JE, Soule HD, Gehani SK, Noto AC, Choudhury S, Chen R, Pienta KJ (1993): Nuclear matrix proteins in normal and breast cancer cells. Cancer Res 53:3394-3398.

Lynch MP, Stein JL, Stein GS, Lian JB (1995): The influence of type I collagen on the development and maintenance of the osteoblast phenotype in primary and pas. saged rat calvarial osteoblasts: modification of expression of genes supporting cell growth, adhesion, and extracellular matrix mineralization. Exp Cell Res 216:35-45.

McKnight RA, Shamay A, Sankaran L, Wall RJ, Hennighausen L (1992): Matrix-attachment regions can impact position-independent regulation of a tissue-specific gene in transgenic mice. Proc Natl Acad Sci U S A 89:6943-6947.

Merriman HL, van Wijnen AJ, Hiebert S, Bidwell JP, Fey E, Lian J, Stein J, Stein GS (1995): The tissue-specific nuclear matrix protein, NMP-2, is a member of the AML/CBF/ PEBP2/runt domain transcription factor family: interactions with the osteocalcin gene promoter. Biochemistry 34:13125-13132.

Muschel R, Khoury G, Reid LM (1986): Regulation of insulin mRNA abundance and adenylation; dependence on hormones and matrix substrate. Mol Cell Biol 6:337-341.

Nardozza TA, Quigley MM, Getzenberg RH: Association of transcription factors with the nuclear matrix. J Cell Biol, in press.

Nelson WG, Pienta KJ, Barrack ER, Coffey DS (1986): The role of the nuclear matrix in the organization and function of DNA. Annu Rev Biophys Chem 15:457-475.

Partin AW, Getzenberg RH, CarMichael MJ, Vindivich D, Yoo J, Epstein JI, Coffey DS (1993): Nuclear matrix protein patterns in human benign prostatic hyperplasia and prostate cancer. Cancer Res 53:744-746.

Pienta KJ, Coffey DS (1992): Nuclear-cytoskeletal interactions: evidence for physical connections between the nucleus and cell periphery and their alteration by transformation. J Cell Biochem 49:1-9.

Pienta KJ, Getzenberg RH, Coffey DS (1991a): Cell struc ture and DNA organization. CRC Rev Eukaryotic Gene Expression 1:355-385.

Pienta KJ, Murphy BC, Getzenberg RH, Coffey DS (1991b): The effect of extracellular matrix interactions on morphologic transformation in vitro. Biochem Biophys Res Comm 179:333-339.

Robinson SI, Small D, Idzerda R, McKnight GS, Vogelstein $B$ (1983): The association of transcriptionally active genes with the nuclear matrix of the chick oviduct. Nuc Acids Res 11:5113-5130.

Wray W, Boulikas T, Wray V, Hancock R (1981): Silver staining of proteins in polyacrylamide gels. Anal Biochem 118:197-203. 